\title{
KEPEMIMPINAN TRANSFORMASIONAL KEPALA MADRASAH DI PROVINSI JAMBI: \\ Studi Multi Kasus pada MAN Olak Kemang Kota Jambi, MAN Pulau Temiang Kabupaten Tebo, dan MAN 2 Kabupaten Tanjung Jabung Timur \\ Sumarto \\ Sekolah Tinggi Agama Islam (STAI) Ma'arif Jambi \\ Jl. KH. Abdurrahman Wahid Kelurahan Talang Bakung Pal Merah Jambi \\ Email: sumarto.manajemeno@gmail.com
}

\begin{abstract}
Abstrak:
Tujuan penelitian ini adalah untuk mengetahui bagaimana kualifikasi, peran dan kunci sukses kepala madrasah transformasional untuk menanamkan budaya belajar pada madrasah di Provinsi Jambi. Pendekatan yang digunakan adalah deskriptif kualitatif. Pengumpulan data menggunakan teknik observasi, wawancara dan dokumentasi. Data dianalisis dengan menggunakan analisis model Miles dan Huberman. Hasil penelitian menunjukkan: Kepala Madrasah transformasional memiliki kepribadian muslim yang baik, mengetahui kebutuhan anggota, memiliki rasa percaya diri, mampu memotivasi dan membangun komitmen bersama dalam melakukan perpindahan menuju perubahan yang lebih baik, kreatif, produktif dan berinovasi, teladan dan berani menghadapi tantangan, memiliki sensitifitas terhadap keluhan dan saran serta mampu bermusyawarah. Agar berhasil dalam perannya, kepala madrasah harus memerankan sebagai direction setter, agent of change, spokesperson, coach, support-getter, succes-guarantor dan path-finder.
\end{abstract}

\begin{abstract}
:
The objective of this study was to find out why the transformational headmaster can instill islamic school culture, the role of transformational leadership and the success of transformational leadership role in instilling islamic shool culture in province of Jambi. The approach used in this study is a qualitative descriptive approach. Data collection techniques using observation, interviews and documentation. Analysis of the data using the model of Miles and Huberman. Research result; Principals have a muslim personality as Prophet, know the needs of his staff, build his staff confidence, building a shared commitment to make the shift towards change for the better, creative, productive and innovative, exemplary and courage to face challenges, sensitive to complaints and suggestions of staff, deliberation and spirit of motivation. Principal transformational leadership roles are as Direction Setter, Agent of Change, Spokesperson, Coach, support-getter, succes-guarantor and path-finder.
\end{abstract}

\section{Kata Kunci: \\ Kepemimpinan Transformasional, Budaya Belajar Madrasah}

PEMIMPIN transformasional adalah individu yang memiliki profil kepemimpinan yang mampu menjelaskan bagaimana dia memimpin, mengubah tim atau lembaga dengan menciptakan, mengkomunikasikan dan membuat model visi dan memberi inspirasi kepada para guru atau pegawai lainnya untuk berusaha mencapai visi itu. Budaya madrasah adalah salah satu strategi pendidikan untuk menanamkan nilai (va- 
lue) secara komprehensif. Dalam perwujudannya, nilai-nilai itu menjadi standar teladan dalam mempersiapkan generasi muda agar dapat hidup mandiri dan keputusan moral secara bertanggung jawab di kehidupannya kelak.

Grand tour yang dilakukan peneliti terhadap tiga Madrasah yang ada di Provinsi Jambi, yaitu MAN Olak Kemang Kota Jambi, MAN Pulau Temiang Kabupaten Tebo dan MAN 2 Kabupaten Tanjung Jabung Timur menunjukkan keunggulan-keunggulan yang dapat diamati melalui observasi dan wawancara dengan Kepala Madrasah. Beberapa fakta yang dapat diungkap dalam tulisan ini adalah; (1) lingkungan Madrasah terletak di pusat aktifitas desa atau kelurahan sehingga aktifitas Madrasah sangat dekat dengan lingkungan masyarakat sekitar dan masyarakat menjadi bagian dari kegiatan dan kemajuan Madrasah; (2) Selalu ada upaya yang dilakukan oleh Kepala Madrasah dalam meningkatkan kualitas para guru dengan mengikutkan mereka dalam kegiatan pelatihan (training) baik tingkat kabupaten/kota, provinsi hingga tingkat nasional seperti penyiapan trainer Kegiatan olympiade sains dan agama tingkat nasional yang dilaksanakan oleh Kementerian Agama RI dan Kementrian Pendidikan Nasional; (3) Budaya Madrasah erat dengan budaya religiusitas masyarakat Melayu seperti hafalan al-Qur'an, sholat dhuha, marawis, pidato bahasa Arab, kegiatan yasinan dan lain sebagainya. Kegiatan relegius yang ada di madrasah jelas mendukung kegiatan akademik di lingkungan sekolah.

Secara spesifik, gambaran profil madrasah, masing-masing dapat dideskripsikan sebagai berikut:

MAN Olak Kemang berada di Kelurahan Olak Kemang Kecamatan Danau Teluk Seberang Kota Jambi. Secara geografis, madrasah berlokasi di wilayah rawan banjir sehingga bangunan Madrasah dibuat berbentuk panggung. MAN Olak Kemang Kota Jambi adalah MAN tertua di Jambi. Madrasah ini dekat dengan situasi sosial dan budaya pesantren. Madrasah ini berdiri diantara pesantren, salah satunya adalah Pondok Pesantren As'ad. Posisi itu menciptakan interaksi religius. Jumlah guru di MAN Olak Kemang Kota Jambi sebanyak 22 orang berstatus PNS, dan 14 orang guru honorer serta orang 11 tenaga kependidikan dengan status akreditasi madrasah B.

Sebagai madrasah tertua yang berdiri di kota ini, MAN Olak Kemang memiliki banyak keunggulan terutama dalam bidang sosial dan budaya. Tenaga pendidik di MAN Olak Kemang Kota Jambi secara periodeik mengikuti pelatihan baik di tingkat kota dan provinsi maupun nasional, seperti pelatihan dalam mempersiapkan peserta didik untuk mengikuti kegiatan olympiade baik tingkat local maupun nasional.

Berbagai prestasi dalam bidang akademik, seni dan olahraga diperoleh peserta didik. Diantaranya adalah juara 1 pada lomba yang diselenggarakan Pusat Informasi Konsultasi Remaja Tingkat Kota Jambi dan Juara Harapan 1 Tingkat Provinsi Jambi yang diadakan oleh BKKBN Bagian Pendidikan Usia Dini dalam Perkawinan. Juara 3 Olimpiade Sains yang diadakan oleh Mahasiswa UNJA dan Juara 2 Pertandingan Sepak Bola Liga Pelajar Indonesia (LPI) Provinsi jambi.

MAN Pulau Temiang Kabupaten Tebo berdasarkan hasil wawancara awal yang dilakukan oleh peneliti di MAN Pulau Temiang, jumlah guru PNS sebanyak 10 orang 
dan guru honorer 14 orang. Jumlah siswa sebanyak 352 orang. Budaya madrasah bercorak tradisional menuju modern dimana para guru yang sudah mulai merespon informasi up date dan bersifat e-information. Meskipun demikian, para guru menjalankan tugas dan fungsinya hanya berdasarkan kebiasaan yang ada. Peran aktif dari Kepala Madrasah berpengaruh terhadap para guru sudah mulai memperhatikan job description yang sudah ditetapkan. (Hasil Wawancara dengan Purwadi, S.Pd [Kepala MAN Pulau Temiang Tebo] Tanggal 16 Februari 2015)

Kepala Madrasah selalu berupaya meningkatkan kualitas akademik dengan pembiasaan belajar dan koordinasi dengan para guru dan tenaga kependidikan dengan wujud pelaksanaan tradisi rapat sebulan sekali, rapat persiapan dalam melaksanakan setiap program Madrasah dan keterbukaan serta sikap toleransi saling menghargai menghormati sebagai bukti untuk memimpin rapat tidak harus selalu kepala madrasah tetapi boleh yang lain sesuai dengan kemampuan dan keahlian. Kepala madrasah dengan segala keterbatasan yang dimiliki selalu memiliki komitmen dan semangat untuk melakukan perubahan di MAN Pulau Temiang. Keunggulan yang sudah tercapai yaitu dengan perolehan akreditasi B MAN Pulau Temiang Kabupaten Tebo dan mendapatkan bantuan beasiswa bagi para siswa sehingga sangat membantu bagi siswa-siswi yang kurang mampu tetapi berprestasi. MAN 2 Kabupaten Tanjung Jabung TimurBerdasarkan hasil wawancara awal yang dilakukan oleh peneliti yaitu jumlah guru PNS 6 orang dan guru honor 14 orang. Jumlah siswa kelas X dan XI sebanyak 97 orang dan kelas XII 64 orang. Budaya madrasah yang ada yaitu didasarkan pada tata tertib dan Dasa Prasetya Siswa yang selalu diupayakan untuk dijalankan dengan baik terutama dalam menjaga nama baik Madrasah. (Hasil Wawancara dengan Drs. Sumanto, S.Pd [Kepala MAN 2 Tanjung Jabung Timur] Tanggal 20 Maret 2015)

Kepala MAN 2 Tanjung Jabung Timur sudah melakukan banyak perubahan yang membudaya yaitu tradisi rapat yang selalu dilakukan kepala Madrasah dalam menyelesaikan masalah dilaksanakan 4 x setahun yaitu rapat UN, rapat PPDB, rapat semesteran, rapat kenaikan kelas dan rapat yang sifatnya insidental. MAN 2 Kabupaten Tanjung Jabung Timur masih berdiri selama 5 tahun tetapi sudah banyak pencapaian keunggulan yang dilakukan sebagai upaya untuk mewujudkan visi misi dan program kerja. Budaya madrasah yang masih tetap dipertahankan yaitu sebelum masuk kelas para siswa wajib membaca surat yasin secara bersamaan, praktek sholat jenazah dan safari ramadhan. Adapun judul penelitian yang diangkat dalam penelitian ini adalah Kepemimpinan Transformasional dalam Menanamkan Budaya Madrasah di Provinsi Jambi (Studi di MAN Olak Kemang Kota Jambi, MAN Pulau Temiang Kabupaten Tebo dan MAN 2 Tanjung Jabung Timur).

Rumusan masalah penelitian ini adalah: (1) Mengapa kepemimpinan transformasional dapat menanamkan budaya madrasah di Provinsi Jambi? (2) Bagaimana kepemimpinan transformasional di madrasah dalam Provinsi Jambi? (3) Bagaimana kepemimpinan transformasional mempengaruhi upaya penanaman budaya madrasah di Provinsi Jambi? dan, (4) Bagaimana keberhasilan kepemimpinan transformasi- 
onal dalam menanamkan budaya madrasah di Provinsi Jambi? Adapun fokus dari penelitian ini adalah mendeskripsikan secara mendasar dan menemukan konsep kepemimpinan transformasional dalam upaya menanamkan budaya madrasah di Provinsi Jambi.

\section{KAJIAN TEORETIS}

\section{Kepemimpinan Transformasional}

Kepemimpinan adalah kemampuan dan keterampilan seseorang dalam mempengaruhi perilaku orang lain ke arah pencapaian (tujuan). Hoy dan Miskel mengatakan bahwa kepemimpinan adalah pengaruh antar pribadi yang dijalankan dalam suatu situasi tertentu, yang diarahkan melalui proses komunikasi ke arah satu atau beberapa tujuan tertentu. ${ }^{1}$

Kepemimpinan menjelaskan bahwa berkaitan dengan pengikutsertaan seluruh anggota atau pengikutnya beradaptasi dengan perubahan dalam mencapai tujuan-tujuan individu maupun organisasi serta mengkoordinasikan secara aktif tugas-tugas yang perlu dalam mencapai keberhasilan. ${ }^{2}$ Menurut Abdul Azis Wahab, kepemimpinan mencakup unsur-unsur sebagi berikut: a) Unsur pemimpin atau orang yang mempengaruhi; b) Unsur interaksi atau kegiatan/usaha dan proses mempengaruhi; c) Unsur tujuan yang hendak dicapai dalam proses mempengaruhi; d) Unsur perilaku/kegiatan yang dilakukan sebagai hasil mempengaruhi. ${ }^{3}$ Kepemimpinan juga diartikan sebagai suatu proses kegiatan seseorang untuk menggerakan orang lain, untuk melaksanakan sesuatu dengan memimpin, membimbing, mempengaruhi orang lain, untuk melakukan sesuatu agar dicapai hasil yang diharapkan. ${ }^{4}$ Menurut Jonson, Jeffry dan Michael, leadership as the use of power and influence to direct the activities of followers toward goal achievement. ${ }^{5}$

Ricky W. Griffin dan Gregory Moorhead membagi definisi kepemimpinan menjadi $d u a$ bagian yaitu sebagai proses dan properti. Sebagai suatu proses, kepemimpinan adalah penggunaan pengaruh tanpa paksaan untuk mengarahkan dan mengkoordinasikan kegiatan anggota kelompok ke arah pencapaian tujuan. Sebagai properti, kepemimpinan adalah karakteristikyang dikaitkan dengan orang-orang yang dianggap mempekerjakan pengaruh tersebut berhasil. ${ }^{6}$

Kepemimpinan adalah pola tingkah yang dirancang untuk mengintegrasikan tujuan organisasi dengan tujuan individu untuk mencapai suatu tujuan atau dengan kata lain kepemimpinan berkaitan dengan proses yang disengaja dari seseorang untuk menekankan pengaruhnya yang kuat terhadap orang lain untuk membimbing, membuat struktur, memfasilitasi aktivitas dan hubungan di dalam kelompok atau organisasi. ${ }^{7}$ Kepemimpinan adalah proses mengarahkan dan mempengaruhi aktivitasaktivitas tugas dari orang-orang dalam kelompok. Kepemimpinan berarti melibatkan orang lain, yaitu bawahan atau karyawan yang akan dipimpin, kepemimpinan juga melibatkan pembagian kekuasaan (power). ${ }^{8}$ Pemimpin yang efektif adalah pemimpin yang menggunakan gaya yang dapat mewujudkan sasarannya, misalnya dengan mendelegasikan tugas, mengadakan komunikasi yang efektif, memotivasi bawahannya, melaksanakan kontrol dan seterusnya. ${ }^{9}$ 
Kepemimpinan adalah kemampuan dan keterampilan seseorang dalam mempengaruhi perilaku orang lain ke arah pencapaian (tujuan). Hoy dan Miskel mengatakan bahwa kepemimpinan adalah pengaruh antar pribadi yang dijalankan dalam suatu situasi tertentu, yang diarahkan melalui proses komunikasi ke arah satu atau beberapa tujuan tertentu. ${ }^{10}$

Ide teori kepemimpinan transformasional atau transformational leadership diawali oleh James McGregor Burnsdalam bukunya yang mendapat pulizer dan National Book Award yang berjudul Leadership. Burns dalam Sudarwan Danim dan Suparno menggunakan istilah mentransformasi kepemimpinan (transforming leadership), di mana yang mentransformasikan adalah kepemimpinannya dari peimimpin ke pengikut. ${ }^{11}$

Kepemimpinan transformasional, Leithwood dkk, mengemukakan: “Transformational leadership is seen to be sensitive to organization building, developing shared vision, distributing leadership and building school cultute necessary to current restructuring effors in schools". Esensi pendapat ini, bahwa kepemimpinan transformasional memiliki ciri dominan, yaitu: memiliki sensitivitas terhadap pengembangan lembaga, mengembangkan visi bersama antarkomunitas lembaga, mendistribusikan peran kepemimpinan, mengembangkan kultur madrasah danmelakukan usaha-usaha restrukturisasi di madrasah. ${ }^{12}$

Bass dalam Yukl menjelaskan bahwa perilaku kepemimpinan transformasional dapat dikategorikan dalam empat hal berikut: 1) Pengaruh ideal. Perilaku idela adalah perilaku yang membangkitkan emosi dan identifikasi yang kuat dari pengikut terhadap pemimpin. 2) Pertimbangan individual. Pertimbangn individual meliputi pemberian dukungan, dorongan, dan pelatihan bagi pengikut. 3) Motivasi inspiration. Motivasi inspiration meliputi penyampaian visi yang menarik, dengan menggunakan simbol untuk memfokuskan upaya bawahan, dan membuat model perilaku yang tepat. 4) Stimulasi intelektual. Stimulasi intelektual adalah perilaku yang meningkatkan kesadaran pengikut akan permasalahan dan mempengaruhi para pengikut untuk memandang masalah dari perspektif yang baru. Perilaku kepemimpinan transformasional memiliki indikator: 1) Pengaruh ideal. 2) Pertimbangan individual. 3) Motivasi inspiration. 4) Stimulasi intelektual. ${ }^{13}$

Bass dan Aviola dalam Aan Komariah dan Cepi Triatna mengusulkan empat dimensi dalam kadar kepemimpinan transformasional dengan konsep 4 "I"14 yang artinya: "I" pertama adalah idealiced influence, yang dijelaskan sebagai perilaku yang menghasilkan rasa hormat(respect) dan rasa percaya diri(trust) dari orang yang dipimpinnya. Idealized influence mengandung makna saling berbagi risiko melalui pertimbangan kebutuhan para staf diatas kebutuhan pribadi dan perilaku moral secara etis. "I" kedua adalah inspirational motivation, tercermin dalam perilaku yang senantiasa menyediakan tantangan bagi pekerjaan yang dilakukan staf dan memperhatikan makna pekerjaan bagi staf. Pemimpin menunjukkan atau mendemonstrasikan komitmen terhadap sasaran organisasi melalui perilaku yang dapat diobservasi staf. Pemimpin adalah seorang motivator yang bersemangat untuk terus membangkitkan antusiasme dan optimisme staf. 
"I" ketiga adalah intelelectual stimulation, yaitu pemimpin yang mempraktikan inovasi-inovasi. Sikap dan perilaku kepemimpinannya didasarkan pada ilmu pengetahuan yang berkembang dan secara intelektual ia mampu menerjemahkannya dalam bentuk kinerja yang produktif. Sebagai intelektual, pemimpin senantiasa menggali ide-ide baru dan solusi yang kreatif dari para staf dan tidak lupa selalu mendorong staf mempelajari dan mempraktikkan pendekatan baru dalam melakukan pekerjaan. "I" keempat adalah individualized consideration, pemimpin merefleksikan dirinya sebagai seorang yang penuh perhatian dalam mendengarkan dan menindak lanjuti keluhan, ide, harapan-harapan, dan segala masukan yang diberikan staf. Dapat dilihat pada gambar di bawah ini:

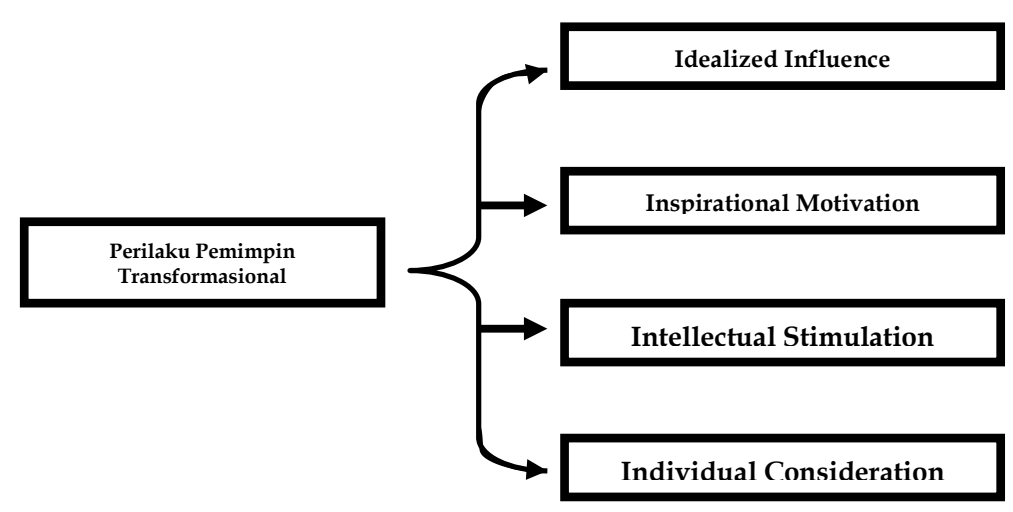

Gambar 1: Perilaku Kepempinan Transformatif

Rasulullah SAW sebagai pemimpin yang sempurna, sebelum terjun ke medan perjuangan Islam, telah membuat perencanaan yang matang, sehingga dalam mensyi' arkan Islam selalu berhasil dan perlahan-lahan para pengikutnya bertambah banyak. Setelah Islam tersebar luas, perjuangan Rasulullah tidak berhenti. Rasulullah SAW mengajarkan kepada umatnya untuk membangun kekhalifahan. Kekhalifahan ini dimaksudkan supaya perjuangan Islam harus terus berjalan walaupun suatu saat Rasulullah Saw. wafat. Ini merupakan visi jangka panjang Rasulullah. Prinsip kepemimpinan Islam menurut Ismail Noor, yaitu: syura (musyawarah) (QS. Asy-Syura (42) ayat 38 dan QS. Ali Imron (3) ayat 159), 'adl bi al-qisth (keadilan dengan kesetaraan) (Q.S. An-Nisa, 58, Q.S. An-Nisa (4) : 135 dan Q.S. Al-Maidah (5) ayat 8), dan hurriyah al-kalam (kebebasan berekspresi dengan adab al-ikhtilaf) (Q.S. Al Hasyr ayat 18). ${ }^{15}$

Tiga prinsip kepemimpinan manajerial Nabi Muhammad SAW Versi Ismail Noor ${ }^{16}$, yaitu;

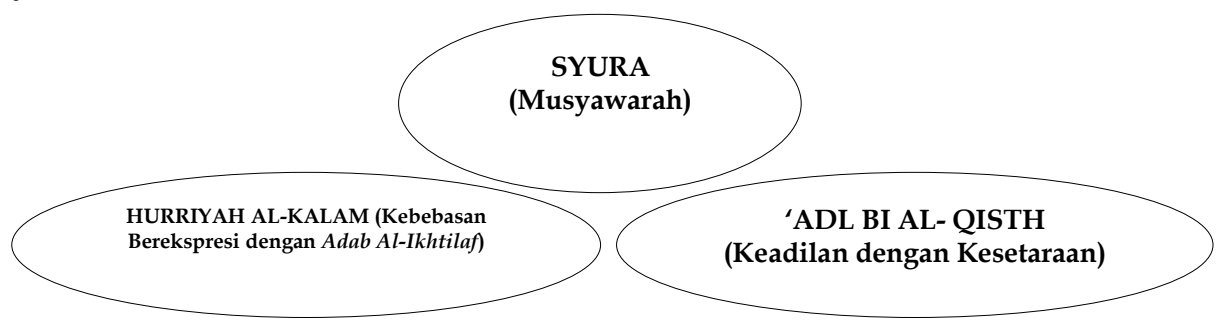

Gambar 2: Tiga prinsip kepemimpinan manajerial Nabi Muhammad SAW 
Kepemimpinan transformer yaitu kemampuan menciptakan dan mengartikulasikan visi yang realistis, dapat dipercaya, dan menarik tentang masa depan organisasi atau unit organisasi yang terus tumbuh dan meningkat dibanding saat ini. Visi ini memiliki gambaran yang jelas dan mendorong, yang menawarkan cara yang inovatif untuk memperbaiki, yang mengakui dan berdasarkan tradisi serta terkait dengan tindakan-tindakan yang dapat diambil orang untuk merealisasikan perubahan. ${ }^{17}$

\section{Budaya Madrasah}

Budaya atau kebudayaan berasal dari bahasa sansekerta yaitu buddhayah, yang merupakan bentuk jamak dari buddhi (budi atau akal) diartikan sebagai hal-hal yang berkaitan dengan budi dan akal manusia, dalam bahasa Inggris kebudayaan disebut culture yang berasal dari kata latin colere yaitu mengolah atau mengerjakan dapat diartikan juga sebagai mengolah tanah atau bertani, kata culture juga kadang sering diterjemahkan sebagai "Kultur" dalam bahasa Indonesia. ${ }^{18}$

Budaya adalah suatu pola asumsi dasar yang ditemukan dan ditentukan oleh suatu kelompok tertentu karena mempelajari dan menguasai masalah adaptasi eksternal dan integrasi internal, yang telah bekerja dengan cukup baik untuk dipertimbangkan secara layak dan karena itu diajarkan pada anggota baru sebagai cara yang dipersepsikan, berpikir dan dirasakan dengan benar dalam hubungan dengan masalah tersebut. 19

Koentjaraningrat berpendapat bahwa "kebudayaan" berasal dari kata sansekerta buddhayah bentuk jamak dari buddhi yang berarti budi atau akal, sehingga menurutnya kebudayaan dapat diartikan sebagai hal-hal yang bersangkutan dengan budi dan akal, ada juga yang berpendapat sebagai suatu perkembangan dari majemuk budi daya yang artinya daya dari budi atau kekuatan dari akal. ${ }^{20}$ Koenjtaraningrat berpendapat bahwa unsur kebudayaan mempunyai tiga wujud, yaitu pertama sebagai suatu ide, gagasan, nilai-nilai norma-norma peraturan dan sebagainya, kedua sebagai suatu aktifitas kelakuan berpola dari manusia dalam sebuah komunitas masyarakat, ketiga benda-benda hasil karya manusia. ${ }^{21}$

Koentjaraningrat mengelompokkan aspek-aspek budaya berdasarkan dimensi wujudnya, yaitu: Kompleks gugusan atau ide seperti pikiran, pengetahuan, nilai, keyakinan, norma dan sikap. Aktifitas seperti pola komunikasi, tari-tarian, upacaraadat. Material hasil bendaseperti seni, peralatan dan sebagainya. ${ }^{22}$ Sedangkan menurut Robert K. Marton, diantara segenap unsur-unsur budaya terdapat unsur yang terpenting yaitu kerangka aspirasi tersebut, dalam artian ada nilai budaya yang merupakan konsepsi abstrak yang hidup di dalam alam pikiran. ${ }^{23}$

Madrasah model beberapa tahun belakang ini mendapat sorotan banyak pihak. Hal ini terjadi karena, baik di kalangan ahli dan praktisi pendidikan maupun masyarakat, terdapat persepsi yang berbeda tentang praktek dan model Madrasah. Persepsi ini tergantung pada visi dan misi yang digariskan individu maupun lembaga dalam mengkreasi model Madrasah yang berpengaruh terhadap budaya madrasah itu sendiri. ${ }^{24}$ 
Budaya sekolah dengan budaya madrasah memiliki perbedaan, karena budaya madrasah memiliki ciri-ciri khusus dibandingkan dengan sekolah, sebagaimana yang disampaikan oleh Minnah El Widdah, Asep Suryana dan Kholid Musyaddad dalam kepemimpinan berbasis nilai dan pengembangan mutu madrasah yaitu madrasah adalah konsep lembaga pendidikan yang berbasis agama Islam, keberadaannya muncul dikarenakan hasrat kuat masyarakat Islam untuk berperan serta dalam pendidikan dan motivasi keagamaan yang kuat dari para orang tua untuk meningkatkan pendidikan agama anak-anaknya dibandingkan dengan bersekolah di sekolah umum pada biasanya serta adanya anggapan di masyarakat bahwa menyekolahkan anak perempuannya di madrasah merasa lebih aman dengan kata lain madrasah dianggap sebagai benteng moral bagi siswa-siswinya. Begitu juga dengan mata pelajaran yang diperoleh oleh para siswa-siswinya tidak hanya mendapatkan pelajaran agama sebagai ciri khas dari madrasah tetapi juga mendapatkan mata pelajaran umum sebagaimana di sekolah umum biasanya. ${ }^{25}$

Budaya madrasah yang kondusif mendorong semua warga madrasah untuk bertindak dan melakukan sesuatu yang terbaik yang mengarah pada prestasi siswa yang tinggi. ${ }^{26}$ Budaya madrasah lebih berkaitan dengan aspek-aspek informal dari organisasi dari pada elemen-elemen resminya yang selalu dilambangkan dengan gambaran struktur. Budaya fokus terhadap nilai-nilai, keyakinan-keyakinan dan normanorma individu dan bagaimana persepsi-persepsi ini bergabung atau bersatu dalam makna-makna organisasi. ${ }^{27}$ Suatu persepsi bersama yang dianut oleh anggota organisasi tersebut dinamakan budaya organisasi. Budaya ini dapat terwujud dalam filosofi, ideologi, nilai-nilai, asumsi, keyakinan serta sikap dan norma bersama anggota-anggota organisasi tersebut dalam memandang realitas, terutama berkaitan dengan permasalahan internal maupun eksternal. ${ }^{28}$

\section{METODE PENELITIAN}

Penelitian ini menggunakan pendekatan penelitian kualitatif deskriptif analitis, menurut Noeng Muhadjir penelitian kualitatif lebih konsekuen yaitu sesuai dengan keadaan di lapangan dalam memperoleh hasil deskripsi di lapangan. ${ }^{29}$ Metode deskriptif yaitu metode yang menggambarkan gejala-gejala yang ada pada saat penelitian. Penelitian kualitatif adalah prosedur penelitian yang menghasilkan data deskriptif berupa kata-kata tertulis atau lisan dari orang-orang atau pelaku yang dapat diamati. ${ }^{30}$ Penelitian ini merupakan studi kasus sehingga hasilnya bukan merupakan representasi Madrasah yang lain. Oleh karena itu kajian yang demikian menurut Sukmadinata tidak ditujukan untuk membuat generalisasi, tetapi untuk memperluas temuan yang memungkinkan pembaca atau peneliti lain dapat memahami situasi yang sama dan menggunakan hasil penelitian ini dalam praktik. ${ }^{31}$ Tempat penelitian di MAN Olak Kemang Kota Jambi, MAN Pulau Temiang Kabupaten Tebo dan MAN 2 Kabupaten Tanjung Jabung Timur. Subjek penelitian Kepala madrasah, wakil kepala madrasah, perwakilan guru, tenaga kependidikan dan siswa-siswi dengan purposive sampling. Teknik pengumpulan data dengan observasi partisipatif, wawancara dan 
studi dokumentasi dengan teknik snawball. Analisis data dengan model Miles dan Huberman. Teknik keabsahan data menggunakan traiangulasi data.

\section{TEMUAN ANALISIS PENELITAN TENTANG ZAKAT}

Kepala madrasah yang transformasional menanamkan budaya madrasah di Provinsi Jambi (MAN Olak Kemang Kota Jambi, MAN Pulau Temiang Kabupaten Tebo dan MAN 2 Tanjung Jabung Timur) dengan integritas keagamaan yang baik yaitu memiliki kepribadian muslim sebagaimana yang dicontohkan Rasulullah SAW menjadi pemimpin yang mengetahui kebutuhan anggotanya, memiliki komitmen bersama, melakukan kerja kreatif dan inovatif, berani menghadapi tantangan sehingga dapat terlihat dalam aksinya di Madrasah yaitu (1) Memiliki kemampuan untuk mengelola lembaga pendidikan Islam secara porfesional berbasiskan pada akuntabilitas, transparansi dan efisiensi; (2) Memiliki rancangan pengembangan yang transformasional; (3) Memiliki sarana dan fasilitas pembelajaran yang memadai, seperti perpustakaan, laboratorium dan sebagainya serta mampu memberdayakan sarana lain yang dapat digunakan lagi; (4) Memiliki tenaga pendidik dan kependidikan yang memenuhi tuntutan kualifikasi dan kompetensi; (5) Menggunakan kurikulum dan metode pembelajaran yang mencerminkan pembelajaran yang memenuhi standar PAIKEMI (praktis, aktif, inovatif, kreatif, efektif, menyenangkan dan Islami); (6) Memiliki keunggulan dalam bidang agama dan ilmu pengetahuan; (7) Mengembangkan kemampuan bahasa asing; dan (8) Memberikan keterampilan teknologi.

Peran kepemimpinan transformasional kepala madrasah (MAN Olak Kemang Kota Jambi, MAN Pulau Temiang Kabupaten Tebo dan MAN 2 Tanjung Jabung Timur). Melakukan to transform yaitu perpindahan untuk melakukan perubahan yang lebih baik, kepala madrasah melakukan perannya sebagai penentu arah (Direction Setter), pemimpin mesti menyeleksi dan menetapkan sasaran dengan mempertimbangkan lingkungan eksternal masa depan yang menjadi tujuan pengerahan seluruh sumber daya organisasi. Kemudian agen perubahan (Agent of Change). Dalam perannya sebagai agen perubahan, pemimpin transformer bertangggungjawab untuk merangsang perubahan di lingkungan internal.Juru Bicara(Spokesperson). Seorang pemimpin efektif adalah juga seorang yang mengetahui dan menghargai segala bentuk komunikasi yang tersedia, guna menjelaskan dan membangun dukungan. Pelatih (Coach). Pemimpin transformer yang efektif harus menjadi pelatih yang baik. Dengan ini berarti bahwa seorang pemimpin harus menggunakan kerjasama kelompok untuk mencapai perpindahan perubahan. Pemimpin transformasional kepala madrasah sebagai Pembangkit motivasi. Dalam perspektif masa kini, seorang pemimpin berperan sebagai motivator bagi anggota internalnya. Penggalang dukungan (support-getter). Dalam perspektif masa kini, pemimpin berperan sebagai penggalang dukungan dari anggota eksternalnya sehingga dukungan diberikan.Penjamin sukses (succes-guarantor). Dalam perspektif masa depan, seorang pemimpin berperan sebagai penjamin sukses di mata anggotanya dengan menyediakan kepastian akan masa depan yang lebih baik. Pemandu jalan (path-finder). Dalam perspektif masa depan, seorang pemimpin berperan sebagai pemandu jalan menuju perpindahan perubahan yang lebih baik. 
Peran kepemimpinan transformasional kepala madrasah dalam menanamkan budaya madrasah di Provinsi Jambi (MAN Olak Kemang Kota Jambi, MAN Pulau Temiang Kabupaten Tebo dan MAN 2 Tanjung Jabung Timur), yaitu a) Idealiced influence (rasa hormat (respect), Rasa percaya diri (trust), Mengembangkan visi bersama, Mengembangkan budaya kerja, Melakukan usaha-usaha restrukturisasi, Memberdayakan anggotanya, Perilaku moral secara etis serta teladan. b) Inspirational motivation (Menghadapi tantangan, Memperhatikan makna pekerjaan, Menunjukkan komitmen, Motivator yang bersemangat untuk terus membangkitkan antusiasme dan optimisme anggotanya). c) Intelelectual stimulation (Perilaku inovasi, kepemimpinan didasarkan pada ilmu pengetahuan yang berkembang dan secara intelektual ia mampu menerjemahkannya dalam bentuk kinerja yang produktif, Menggali ide-ide baru dan solusi yang kreatif dan mendorong anggotanya mempelajari dan mempraktikkan pendekatan baru dalam melakukan pekerjaan. d) Individualized consideration (Penuh perhatian dalam mendengarkan dan menindak lanjuti keluhan, ide, harapan-harapan dan segala masukan yang diberikan anggotanya dan Memiliki sensitivitas terhadap pengembangan lembaga.

Keberhasilan peran kepemimpinan transformasional dalam meningkatkan budaya madrasah di Provinsi Jambi. Faktor-faktor keberhasilan adalah faktor kepribadian pemimpin yang baik, faktor pendidikan dan pengalaman yang tinggi, faktor internal dan faktor eksternal yaitu kerja sama yang baik di dalam madrasah dan di luar madrasah dengan pihak lain untuk mencapai kemajuan dan perubahan madrasah yang lebih baik dan bermanfaat yaitu dalam 1) aspek proses belajar mengajar, 2) prestasi belajar para siswa di dalam Madrasah dan mengikuti event/ kegiatan eskul di luar madrasah, 3) peningkatan kualitas mengajar guru melalui kegiatan ilmiah, 4) peningkatan fasilitas madrasah sebagai penunjang keberhasilan belajar mengajar, 5) menjalin kerja sama yang baik secara internal di dalam madrasah dan eksternal di luar madrasah, 6) menegakkan budaya disiplin kepada seluruh warga madrasah dan membudayakan/ membiasakan menjalankan perintah Agama seperti sholat berjamaah, membaca surat Yasin Tahlil Takhtim Doa, melaksanakan praktek sholat jenazah, melaksanakan praktek ruqyah, menghafal Al Qur'an khusus Juz 30, mampu dengan baik Baca Tulis Al Qur'an, budaya 5 S (sapa, senyum, salam, sopan dan santun), budaya disiplin (datang tepat pada waktunya, isi daftar hadir, siapkan sarana kerja bagi guru perangkat pembelajaran bagi para siswa buku mata pelajaran atau perangkat belajar, patuhi semua peraturan, laksanakan tugas yang menjadi kewajiban dan wewenang, izin apabila tidak hadir dan norma dan nilai sebagai paraturan yang menjadi buah dari budaya yang harus membudaya), dalam peningkatan budaya madrasah yaitu: 1) budaya merupakan keyakinan, 2) kebijakan, 3) norma dan kebiasan dalam madrasah yang dapat dibentuk, diperkuat dan dipelihara melalui pimpinan dan guru-guru di sekolah serta budaya madrasah berpengaruh tidak hanya pada kegiatan warga madrasah tetapi juga motivasi dan semangatnya.

Peningkatan budaya madrasah perlu memperhatikan beberapa hal yaitu: Pertama: Peningkatan budaya madrasah membutuhkan pemimpin transformasional yang 
perubah, memiliki sensitivitas terhadap pengembangan lembaga, mengembangkan visi bersama antarkomunitas lembaga, mendistribusikan peran kepemimpinan, mengembangkan kultur madrasah, melakukan usaha-usaha restrukturisasi di madrasah, memberi teladan dan memberdayakan bawahan, memiliki visi utama, misi, yang menjadi uaraian apa saja yang harus dilakukan dan menjadi indikator keberhasilan pencapaian visi,tujuan, sasaran, target rencana tindakan yang telah dibuat dengan matang, teladan sebagai model untuk perubahan, memiliki integritas kepribadian muslim dan bermusyawarah serta semangat kekeluargaan.

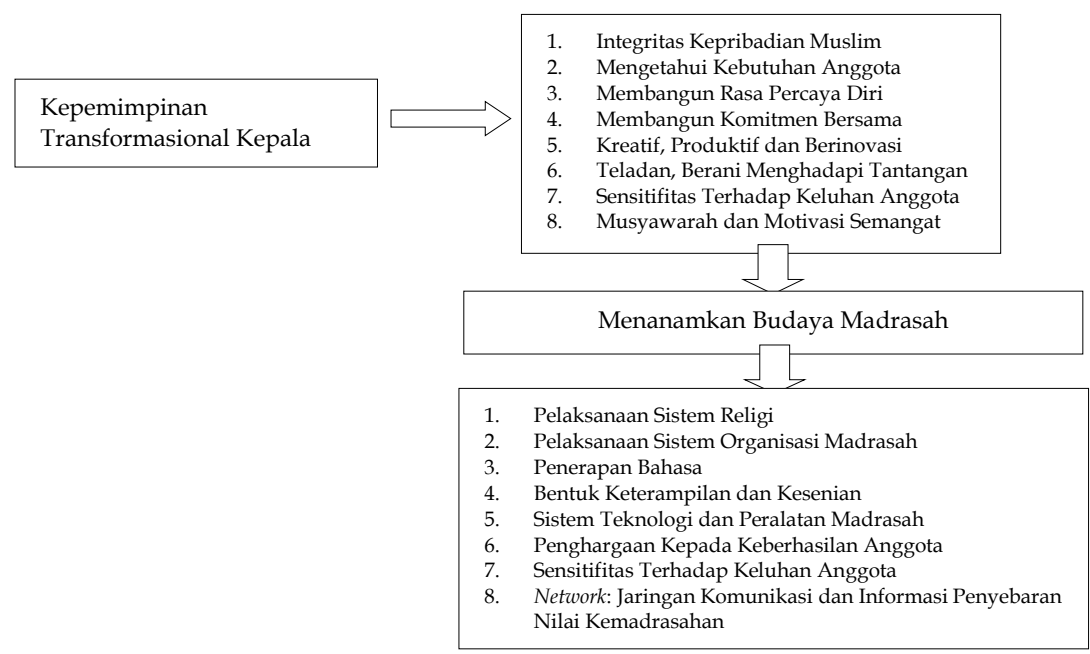

Gambar 3: Model pengembangan Teori Kepemimpinan Transformasional dalam menanamkan Budaya Madrasah

Kedua: Peningkatan budaya madrasah harus dilakukan dengan peran pemimpin yang transformasional yaitu idealiced influence, inspirational motivation, intelelectual stimulation, individualized consideration. Peran-peran tersebut dijalankan secara aktif, optimal dan berkarakter integritas religius dalam mewujudkan penanaman budaya madrasah sehingga dapat terwujud budaya madrasah yang membudaya berdasarkan keyakinan, kebijakan, norma dan kebiasan dalam madrasah yang dapat dibentuk, diperkuat dan dipelihara melalui pimpinan dan guru-guru di madrasah.

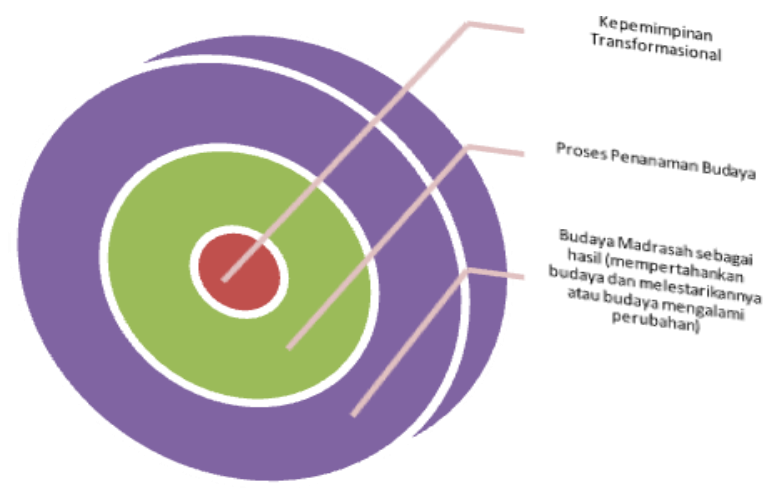

Gambar 4: Model Pengembangan Penanaman Budaya Madrasah 
Peran Kepemimpinan Transformasional berada pada sentral atau pusat yang melakukan perubahan di Madrasah dengan menerapkan 4 "I" yaitu Idealiced Infulence, Inspirational motivation, Intelelectual stimulation,Individualized consideration dengan prinsip Kekeluargaan, Musyawarah dan berdasarkan tauhid keimanan kepada Allah SWT. Kepala Madrasah menanamkan budaya madrasah dengan peran-peran kepemimpinan transformasionalnya sehingga dapat melakukan perubahan budaya atau mempertahankan budaya yang sudah ada menjadi lestari dan membudaya.

\section{KESIMPULAN DAN REKOMENDASI}

Kesimpulan Penelitian ini adalah kepemimpinan transformasional dalam menanamkan budaya madrasah dengan memiliki integritas kepribadian muslim sebagaimana Rasulullah SAW sebagai pemimpin benar atau mampu bersikap jujur, cerdas memiliki kemampuan pendidikan dan pengalaman yang baik, bertanggung jawab dengan apa yang sudah dilakukan dan memperjuangkan amanah untuk mencapai perubahan yang baik, menyampaikan kebenaran dan mencegah kepada yang munkar, mengetahui kebutuhan anggota, membangun rasa percaya diri dan anggota membangun komitmen bersama dalam melakukan perpindahan menuju perubahan yang lebih baik. Kreatif, Produktif dan Berinovasi. Teladan dan Berani menghadapi tantangan. Sensitifitas terhadap keluhan dan saran anggota. Bermusyawarah dan semangat motivasi untuk melakukan perpindahan perubahan menuju yang lebih baik yaitu budaya Madrasah yang relegius dan berprestasi dalam akademik serta kegiatan ekstrakurikuler.

Rekomendasi dan Saran Penelitian ini supaya Kementrian Agama RI melalui Direktorat Jenderal Pendidikan Islam dapat menjadikan bahan penelitian ini untuk membuat kebijkan tentang pemilihan kepalam madrasah teladan tentunya yang transformasional melalui penilaian yang lebih objektif terhadap perubahan yang dilakukan kepala madrasah di seluruh Indonesia. Kemudian untuk Kepala MAN Olak Kemang Kota Jambi, Kepala MAN Pulau Temiang Kabupaten Tebo, Kepala MAN 2 Kabupaten Tanjung Jabung Timur secara umum kepada Kepala Madrasah dan Sekolah se-Provinsi Jambi supaya menjadikan hasil penelitian ini sabagai kajian akademik dalam melakukan perubahan dimulai dari mengetahui apa sebenarnya yang dibutuhkan oleh para guru, tenaga kependidikan dan siswa-siswi, mendesaian visi misi dan program kegiatan yang memiliki nilai dan perubahan, menjadi bahan pertimbangan akademik dalam membuat kebijakan, bekerja cerdas, kreatif dan inovatif dan berani menghadapi tantangan. Selanjutnya Kepada: Gubernur Provinsi Jambi, Walikota Jambi, Bupati se-Provinsi Jambi, Kepala Dinas se-Pemerintahan Provinsi Jambi supaya hasil penelitian ini dapat menjadi bahan kajian dalam membuat peraturan membangun transformasional kepemimpinan madrasah. Untuk Pimpinan Lembaga Pendidikan Nonformal, Perusahaan dan Organisasi Masyarakat supaya memperhatikan setiap gerakan perubahan yang terjadi dalam perwujudan mendukung peningkatan akademik dan budaya relegius agar memperhatikan peran dari kepemimpinan lembaganya yang menjadi sentral perubahan. 


\section{CATATAN AKHIR:}

1. Hoy K. Wayne dan Miskel. G Cecil, Educational Administration, New York: The McGrawHill Companies, Inc.2008, h. 418.

2. Sudarwan Danim dan Suparno, Manajemen dan Kepemimpinan Transformasional Kekepalasekolahan, Jakarta: Rineka Cipta, 2009, h. 7.

3. Abdul Azis Wahab, Anatomi Organisasi dan Kepemimpinan Pendidikan, Bandung: Alfabeta, 2008, h. 83.

4. Edy Sutrisno, Manajemen Sumber Daya Manusia, Jakarta: Kencana Prenada Media Group, 2012, h. 13.

5. Jason A. Colquitt, Jeffry A. Lepine dan Michael J. Wesson, Organizational Behavior Improving Performance and Commitment in the Workplace, New York, McGraw-Hill, 2009, h. 441.

6. Ricky W. Griffin dan Gregory Moorhead, Organization Behavior, Boston: Hougton Mifalin Company, t.th, h. 347.

7. Gary Yukl, Kepemimpinan dalam Organisasi, Jakarta: Indeks, 2010, h. 3.

8. Mamduh M. Hanafi, Manajemen Risiko (Risk Management), UPP STIM YKPN, h. 328.

9. Husaini Usman, Manajemen Teori, Praktik dan Riset Pendidikan, Jakarta: Bumi Aksara, 2009, h. 293.

10. Hoy K. Wayne dan Miskel. G Cecil, op.cit., h. 418.

11. Sudarwan Danim dan Suparno, op.cit., h. 52 - 53.

12. Sudarwan Danim dan Suparno, ibid., h. 52 - 53.

13. Gary Yukl, op.cit., h. 305.

14. Aan Komariah dan Cepi Triatna, Visionary Leadership Menuju Sekolah Efektif, Jakarta: Bumi Aksara. 2010.

15. Ismail Noor, Manajemen Kepemimpinan Muhammad SAW: Mencontoh Teladan Kepemimpinan Rasul Untuk Kesempurnaan Manajemen Modern. Bandung: Mizan. 2011, h. 23.

16. Ibid. h. 23

17. S.P. Robbins, Organizational Behavior. $6^{\text {th }}$ Edition. New Jersey: Prentice Hall. Inc. Internet Edition, 1993, h. 473.

18. Muhaimin, Islam dalam Bingkai Buduaya Lokal;Potret dari Cirebon, Jakarta: Logos, 2001, h. 153.

19. Jerald, G. and Robert, A.B., Behavior in Organizations, Cornell University: Pearson Prentice 2008, h. 12.

20. Koentjaraningrat, Kebudayaan, Mentalitas dan Pembangunan, Jakarta: Gramedia Pustaka Utama, 1993, h. 9.

21. Ibid., h. 5.

22. Ibid., h. 28

23. Fernandez, S.O, Citra Manusia Budaya Timur dan Barat, NTT: Nusa Indah, 1990, h. 28.

24. M. Ali Hasan dan Mukti Ali, Kapita Selekta Pendidikan Islam, Jakarta: Pedoman Ilmu Jaya, 2006, h. 127.

25. Minnah El Widdah, dkk., Kepemimpinan Berbasis Nilai dan Pengembangan Mutu Madrasah. Bandung: Alfabeta, 2012, h. 24

26. Mulyasa, Manajemen dan Kepemimpinan Kepala Sekolah, Jakarta: Bumi Aksara, 2011, h. 90.

27. Tony Bush dan Marianne Coleman, Manajemen Mutu Kepemimpinan Pendidikan, terj. Fahrurrozi. Yogyakarta: IRCiSoD, 2012, h. 133.

28. Asmaun Sahlan, Mewujudkan Budaya Religius di Sekolah, Upaya Mengembangkan PAI dari Teori ke Aksi, Malang: UIN Maliki Press, 2010h. 73.

29. Noeng Muhadjir, Metodologi Penelitian Kualitatif, Yogyakarta: Rake Sarasin, 2005, h. 86 - 87. 
30. Nurul Zuhriah, Metodologi Penelitian Sosial dan Pendidikan, Jakarta: Bumi Aksara, 2006, h. 1992.

31. Nana Syaodih Sukmadinata, Metode Penelitian Pendidikan, Bandung: Program Pascasarjana Universitas Pendidikan Indonesia, Remaja Rosdakarya, 2007, h. 60 - 61.

\section{DAFTAR PUSTAKA}

Bakhri, Amirul, Kepemimpinan Kepala Madrasah dalam Mengembangkan Budaya Mutu, 2007.

Blumberg \& W. Greenfield, The Effective Principal: Perspectives on School Leadership. Boston: Allyn \& Bacon. 1980.

Blumberg \& W. Greenfield, The Effective Principal: Perspectives; J.M. Kouzes \& B.Z. Posner, The Leadership Challenge; A.L. Manasse, Effective Principals; W.I. Rutherford, School Principals; L.T. Shieve \& M.B. Shoenheit, Vision and the Work Life.

Brock, B.L., \& M.L., Grady, Launcing ; F.C. Lunenburg \& B.J. Irby, The Principalship; Mendez-S. Morse, Characteristics of Leaders of Change, 1992.

Bush, Tony dan Marianne Coleman, Manajemen Mutu Kepemimpinan Pendidikan, terj. Fahrurrozi, Yogyakarta: IRCiSoD, 2012.

Cartwright, J., Cultural Transformation: Nine Factors For Continuous Business Improvement, Singapore: Financial Times/Prentice 2009.

Clark \& S. Clark, Restructuring Middle Level School: Strategies for Using Turning Points, In S. Clark \& D. Clark (Eds.), School in the Midlle: A Decide of Growth and Change. Reston, VA: NASSP. 1990.

Colquitt, Jason A., Jeffry A. Lepine dan Michael J. Wesson, Organizational Behavior Improving Performance and Commitment in the Workplace, New York, McGraw-Hill, 2009.

Crowther, F., S. Kaagan, M. Ferguson, dan L. Hann, Developing Teachers Leaders, Thousand Oaks: Corwin Press, Inc. 2002.

Danim, Sudarwan dan Suparno. Manajemen dan Kepemimpinan Transformasional Kekepalasekolahan, Jakarta: Rineka Cipta, 2009.

Daryanto dan Suryatri Darmiatun, Implementasi Pendidikan Karakter di Sekolah, Yogyakarta: Penerbit Gava Media, 2009.

David, C.T., dan Kerr, I., Cultural Intellegence: People Skill for Global Business, San Francisco: Jossey Bass, Publisher. 2004.

Departemen Agama RI, Al-Qur'an dan Terjemah, Bandung: CV Penerbit Doponegoro, 2010.

Fernandez, S.O, Citra Manusia Budaya Timur dan Barat, NTT: Nusa Indah, 1990.

Griffin, Ricky W., dan Gregory Moorhead, Organization Behavior. Boston: Hougton Mifalin Company, t.th.

Hasan, M. Ali dan Mukti Ali, Kapita Selekta Pendidikan Islam, Jakarta: Pedoman Ilmu Jaya, 2006.

Jerald, G., and Robert, A.B., Behavior in Organizations, Cornell University: Pearson Prentice 2008.

Karwati, Euis dan Donni Juni Priansa, Kinerja dan Profesionalisme Kepala Sekolah Membangun Sekolah yang Bermutu, Bandung: Alfabeta. 2013.

Koentjaraningrat, Kebudayaan, Mentalitas dan Pembangunan, Jakarta: Gramedia Pustaka Utama, 1993.

Komariah, Aan dan Cepi Triatna, Visionary Leadership Menuju Sekolah Efektif, Jakarta: Bumi Aksara. 2010.

Lunenburg, F. C., \& B. J. Irby, The Principalship; J. Murphy, Principal Instructional Leadership, in P.W. Thurston \& L.S. Lotto, Recent Advinces in Educational Administration, Vol.1B., Greenwich, CT: JAI Press. 1990.

Muhadjir, Noeng, Metodologi Penelitian Kualitatif, Yogyakarta: Rake Sarasin, 2005. 
Muhaimin, Islam dalam Bingkai Buduaya Lokal; Potret dari Cirebon, Jakarta: Logos, 2001.

Mulyasa, Manajemen dan Kepemimpinan Kepala Sekolah, Jakarta: Bumi Aksara, 2011.

Noor, Ismail, Manajemen Kepemimpinan Muhammad SAW: Mencontoh Teladan Kepemimpinan Rasul Untuk Kesempurnaan Manajemen Modern, Bandung: Mizan. 2011.

Rusmana, Dadan dan Yayan Rahtikawati, Tafsir Ayat-Ayat Budaya, Bandung: CV. Pustaka Setia, 2014.

S. P. Robbins, Organizational Behavior. $6^{\text {th }}$ Edition. New Jersey: Prentice Hall. Inc. Internet Edition, 1993.

Sahlan, Asmaun, Mewujudkan Budaya Religius di Sekolah, Upaya Mengembangkan PAI dari Teori ke Aksi, Malang: UIN Maliki Press, 2010.

Sukmadinata, Nana Syaodih, Metode Penelitian Pendidikan, Bandung: Program Pascasarjana Universitas Pendidikan Indonesia, Remaja Rosdakarya, 2007.

Sule, Ernie Tisnawati dan Kurniawan Saefullah, Pengantar Manajemen, Jakarta: Kencana, 2006.

Sutrisno, Edy, Manajemen Sumber Daya Manusia, Jakarta: Kencana Prenada Media Group, 2012.

Tim Departemen Agama RI. Al-Qur'an dan Terjemahannya, Jakarta: Departemen Agama RI.

Usman, Husaini, Manajemen Teori, Praktik dan Riset Pendidikan, Jakarta: Bumi Aksara, 2009.

Wahab, Abdul Azis, Anatomi Organisasi dan Kepemimpinan Pendidikan, Bandung: Alfabeta, 2008.

Wayne, Hoy K., dan Miskel G. Cecil, Educational Administration, New York: The McGraw-Hill Companies, Inc.2008.

Widdah, Minnah El, dkk., Kepemimpinan Berbasis Nilai dan Pengembangan Mutu Madrasah, Bandung: Alfabeta, 2012.

Yukl, Gary, Kepemimpinan dalam Organisasi, Jakarta: Indeks, 2010.

Zuhriah, Nurul, Metodologi Penelitian Sosial dan Pendidikan, Jakarta: Bumi Aksara, 2006 